\title{
Pretty past it? interrogating the postfeminist makeover of ageing, style and fashion
}

Deborah Jermyn, Department of Media, Culture and Language, University of Roehampton, London, UK

\begin{abstract}
From the 'Leading Ladies' advertising campaign for UK high-street stalwart Marks and Spencer; to Charlotte Rampling becoming the face of NARS cosmetics at 68 in 2014; and the delight that meets select older women stars such as Helen Mirren on the red carpet in the women's magazine market, it appears that the fashion and celebrity industries of late have opened their arms to embrace stylish 'women of a certain age' to an unprecedented degree. This article scrutinises the reception and complexities that lie at the core of this seeming cultural shift which, at first glance, might be positively construed to demonstrate that at last the disenfranchisement and invisibility endured by older women in these industries - which are central to upholding wider social hierarchies about which women 'matter' - have been dented. Examining recent documentaries and advertising campaigns, I ask: what is at stake in the decision to coopt 'old women' into the (young) marketplace of style and fashion, and in the seeming willingness by many audiences to embrace texts featuring older women as sartorial mavens? The zeitgeist described here arguably underlines how the directive to enact 'self-surveillance, monitoring and discipline' around one's appearance (Gill, 2007) increasingly incorporates an older subject/consumer, and evidences how coercion to submit to 'makeover' culture seemingly never ends. For these reasons, I argue, it is imperative that feminist media studies' critique of the neoliberal, postfeminist climate
\end{abstract}


addresses the widespread neglect of older women in extant cultural analyses, and turns its attention now to the implications of this shift

KEYWORDS Fashion; ageing; postfeminism; advanced style; fabulous fashionistas

"Why write about ageing, when this topic is so daunting, so complicated?"

(Segal 2013, p.1).

\section{Introduction}

Lynne Segal's crucial question, posed on the first page of her polemical 2013 study Out of Time: The Pleasures and the Perils of Ageing, hints at some of the many contexts which inform the dearth of attention to ageing in the history of feminist theory to date, despite it being a fundamental constituent of identity. Segal speaks candidly about wrestling with the discomfort prompted by the task she sets herself in the book, namely "to look more closely at the psychology and politics of ageing" (2013, p.4). Even while wanting to make this intervention, and as one of Western feminism's leading scholar-activists, she admits to "fears of revealing [one's] age when the years start to race by... I have to keep at bay so much anxiety around the subject" (2013, p.1). Advocating a feminist politics does not necessarily make such work easier, then, especially when one recalls that Kathleen Woodward has argued “ageism is entrenched within feminism itself” (1999, p.xi). Writing in 1999, Woodward noted how the second-wave was preoccupied with issues pertaining to younger women; today, this is arguably one of the key ways that postfeminism holds some consistency with this earlier period, in which again the marginalisation of attention to women in the later stages of the life course has been perpetuated. By making the difficulty of 
thinking and writing about ageing the substance of her introduction, Segal sheds further light on the question of why so many feminist theorists have avoided it; critical awareness of the gendered inequities of growing older for most women is perhaps often prompted by the creeping acknowledgement of how one is becoming the subject of those inequities. The process of conceptualising the gendered nature of growing older to some degree, then, necessitates that one "face up to [one's] own anxieties about ageing" $(2013$, p.5) - that one acknowledge one's shifting relationship to the world and indeed to mortality - while as younger women, the experience not so much of ageing but of becoming that most disparaged thing, an old woman, remains somehow unimaginable, seemingly endlessly remote, Other.

Despite the trepidation that conceptualising ageing can bring, a small but significant canon of work marking out feminist interventions into gender and ageing has taken some gradual shape. Key among these, Simone de Beauvoir's La Vieillesse/The Coming of Age in 1970 was closely followed by Susan Sontag's milestone essay 'The Double Standard of Ageing' (1972), and some twenty years later by Germaine Greer's The Change (1991) and Betty Friedan's The Fountain of Age (1993); while alongside Segal above, Kathleen Woodward (Figuring Age: Women, Bodies and Generations (1999)) and Margaret Morganroth Gullette (Declining to Decline: Cultural Combat and the Politics of the Midlife (1997) and Aged by Culture (2004)) have become leading cultural commentators in this regard. As Su Holmes and I have noted elsewhere, this body of work has significantly expanded in more recent years with a burgeoning critical attention to media representations of ageing femininities (Jermyn and Holmes, 2015, pp.12-16). The latest scholarship has evidently been prompted in part by an increasing awareness of the implications of the ageing population. This isa demographic shift being felt internationally that has led too to a context fuelling attention to the perceived problems of generationalism, which has become an increasingly potent and evident cultural touchstone (ibid). At one level, the ageing population 
has prompted fears of a 'grey tsunami', where older people are positioned as an unstoppable drain on resources, and by extension, on younger people. But in tandem with this, and even while accounts of the 'grey tsunami' still speak of the fears that ageing evokes, another newly imagined discourse has evolved. These demographic changes, and most particularly the fact of the 'babyboomer' generation reaching retirement age, have led too to a visible expansion of representations of ageing, not least because of the growing importance of the 'grey dollar'. Across film, TV and advertising, older people are now more regularly than ever before evoked as vital, passionate and purposeful, in ways that would have seemed quite unimaginable a generation ago.

It is precisely this latter cultural shift that this essay is concerned with - most specifically, in relation to what is overwhelmingly regarded as the inherently young world of fashion. For as Julia Twigg has observed, "Fashion and age sit uncomfortably together. Fashion inhabits a world of youthful beauty, of fantasy, imagination, allure... Age by contrast is perceived as a time of greyness, marked by retirement from display or engagement with the erotic and style-conscious" (2013, p.1). The discourse Twigg notes here has an established history in Western culture of course. And one might well have expected that within postfeminism, which, as noted above, has been critiqued in part for its overwhelming interest in and address to a youthful idealised subject (Negra, 2009), such a discourse would have been bolstered further still. Yet in recent years, an apparent cultural shift has gained momentum - one in which older women seem increasingly positioned as credible fashion consumers and arbiters.

\section{She's in fashion: the ageing female subject in vogue}

From the 'Leading Ladies' advertising campaign for UK high-street stalwart Marks and Spencer (where in SS14 the diverse 'models' included figures extending across the age range, from campaigner Baroness Doreen Lawrence (61) to singer Rita Ora (23)); to The 
Guardian's weekly 'Fashion for all ages' feature; to Charlotte Rampling becoming the face of premium cult cosmetics brand NARS at age 68 in 2014; and the regular delight that meets (select) older women stars such as Judi Dench (see Williams 2015) and Helen Mirren on the red carpet in the women's magazine market, it appears that the fashion world and associated industries have opened their arms to embrace 'women of a certain age' to an unprecedented degree. In 2015 this apparent movement burgeoned further still into the rarefied realm of high-end designer fashion with writer Joan Didion being adopted as the face of luxury French brand Céline and photographed by Jürgen Teller at the age of $80^{\mathrm{i}}$; Joni Mitchell modelling for Yves Saint Laurent at 71; 93 year-old Iris Apfel appearing alongside 22 year-old Karlie Kloss for Kate Spade; while Dolce \& Gabbana's SS15 campaign featured three anonymous 'old ladies' in widow's mourning garb sporting flamenco-style D\&G accessories. Although the internet has been a key media for the 'shaming' of ageing femininities, evidence of the same trend can be found online and in film also. Chief among the proliferation of bloggers dedicated to older women and style, Ari Seth Cohen's “Advanced Style” blog featuring his pictures of flamboyant older women photographed on the streets of NYC has registered well over 16 million hits at the time of writing and led to a successful book (2012) and documentary film (dir. Lina Plioplyte, 2014) of the same name; while in 2013, the Channel 4 documentary Fabulous Fashionistas (dir. Sue Bourne, 2013), featuring six spirited styleconscious women with an average age of 80 , trended number one in the UK on Twitter during its broadcast with the hashtag \#fabfashionistas. One must be careful, however, not to overstate the general ubiquity of this shift in a culture where youth is still so overwhelmingly revered, nor to suggest these advertising campaigns speak to a newly representative diversity in these industries; many of the women invoked here are white, the possessors of class privilege and very often the kinds of svelte bodies that women are pressurised to attain and maintain whatever their age, and representing brands that are outside the economic reach of 
most women. Nevertheless, taken together, these instances point to a landscape where the inherent generationalism of style and fashion described by Twigg above seems to be eroding, albeit cautiously; but to what ends?

\section{FIG 1 HERE - Caption:}

\section{Charlotte Rampling as the face of NARS in 2014 aged 68(photo by Deborah Jermyn)}

In this essay I scrutinise some of the complexities that lie at the core of this seemingly burgeoning cultural shift and its reception. Hence in my title I invoke the term 'makeover', as a paradigm which has proven to be central to the postfeminist sensibility and its emphasis on the prospect of the endlessly improve-able self (see Gill, 2007). This is not to suggest that the cultural sites being examined here entail tracing the makeover of the women subjects at their centre. Rather it is to suggest that for contemporary women, representations and the very conception of 'ageing' itself are being transformed or 'made-over' within postfeminist discourse, as it spurns entrenched notions of the later-life stages as a time where women are expected to relinquish interest and pleasure in the sartorial world and recede from visibility. At first glance, this shift might be positively construed to demonstrate that at last the disenfranchisement and invisibility endured by older women in the fashion and celebrity industries - which are central to upholding wider social hierarchies about which women 'matter' - have been dented. But while exploring this perspective, in what follows I point too to the many problems and contradictions this 'makeover' of ageing femininities entails. Drawing on examples of the advertising campaigns and films noted above, and personal interviews with two of the subjects featured in Fabulous Fashionistas (Sue Kreitzman and Bridget Sojourner) as well as the filmmaker Sue Bourne, I ask: what is at stake in the decision to co-opt 'old women' into the (young) marketplace of style and fashion, and in the 
seemingly new cultural willingness to embrace older women as sartorial mavens? The zeitgeist described here arguably underlines how postfeminism's directive to enact "selfsurveillance, monitoring and discipline” around one's appearance (Gill 2007, p.149) increasingly incorporates an older subject/consumer, and evidences how coercion to submit to the 'makeover' paradigm Gill identifies as the substance of postfeminism now seemingly never ends. Thus it is imperative that feminist media studies' critique of the contemporary neoliberal, postfeminist climate does more to address the widespread neglect of older women within extant cultural analyses - and the current moment's new-found fascination with positioning images of older women at the forefront of the fashion and style industries provides a rich space within which to take such intervention further.

\section{"The young are so - well, old hat": Advanced Style takes the stage}

It would be reductive to suggest that a single person or text can herald the initiation of a movement such as that described above, and inevitably there are precedents to what is being explored here. Nevertheless, there is a rationale here to opening with attention to Ari Seth Cohen and the Advanced Style blog he launched in 2008 (advancedstyle.blogspot.com), since his work has both proven hugely popular and been privileged by commentators as constituting the vanguard of this zeitgeist. Hence The New York Times' Chief Fashion Critic Vanessa Friedman noted in 2015, that "The young are so - well, old hat" thanks to "a movement arguably commenced [by] the photographer Ari Seth Cohen" (2015), while in interview Sue Kreitzman observed that "Ari started this old-lady revolution" (2015). Cohen tells how on moving to NYC, and having long been inspired by his glamorous grandmothers, he delighted in seeing stylish older women around the city and began to ask for permission to take their photos and post them on his blog (Cohen n.d.). Thus 'ordinary' women, rather than 
celebrities, are figured as extraordinary, talented, aspirational figures captured in vibrant, living moments as they go about their business in the streets of New York; and in this sense Cohen's pictures also challenge prevailing ideas about older age as a time of retreat from active, public life for women. He explains to readers on the website, "I roam the streets of New York looking for the most stylish and creative older folks... Advanced Style offers proof from the wise and silver-haired set that personal style advances with age" (ibid). The distinction between 'style' and 'fashion' is worth noting here - neither Cohen's documentary subjects nor those of Sue Bourne's Fabulous Fashionistas have any interest in trends and instead privilege the ideal of individualism - but in regular discourse these terms are often used interchangeably to denote simply an interest in dress ${ }^{\mathrm{ii}}$. An Observer Magazine article on Cohen and the then impending 2014 film explained of the blog,

It quickly became a sensation for showcasing one of fashion's most unjustly overlooked demographics: women over 60 . The blog spawned numerous other projects - including a 2012 coffee-table book, now in its seventh print run - and garnered praise from sources as diverse as the New Yorker and Vogue Italia, which called Advanced Style less a street-style blog than "a sociological treatise" on ageing and identity... Barneys' Simon Doonan, in the documentary, calls Cohen's photography “punk and subversive"... Cohen founded his blog to correct what he sees as a fundamental injustice of American culture: the invisibility of older people, particularly women over 60 (Sauers 2014, pp.22-25).

The success of Advanced Style - measured in a number of ways, from the vast volume of hits garnered, the 'serious' and favourable international media attention won, to Cohen's own growing celebrity and the endlessly celebratory gratitude left by readers in the blog's comments section - underlines how the project addresses a desire felt among many women interested in questions of fashion, style and ageing, to encounter more diverse images of older 
women. As one representative blog post put it, "I love these women. I have worked in the fashion industry my entire career and at middle age you are unemployable... These ladies are the true icons of style - not the young girls who are all styled the same by stylists!" ('Denise', October 6 2012, in Cohen n.d.).

Sauers' article slightly misquotes Doonan's description of Advanced Style as "subversive"; he actually refers to it as "punk-rock anarchy", but the point is just the same. Doonan's words signal just how arresting Cohen's photos are, how such an overt celebration of and pleasure in older women as style gurus has a certain confrontational edge to it, and indeed how fashion itself, as Elizabeth Wilson has ardently argued, is "one among many forms of aesthetic creativity which make possible the exploration of alternatives. For after all, fashion is more than a game; it is an art form and a symbolic social system" (1985, p.245) (my emphasis). Also noting how fashion contends with a struggle to be taken 'seriously', Twigg has pointed to the low cultural value widely ascribed to it because of its association with the feminine, the trivial and superficial (2013, p.4). This extends to its existence both as a topic of everyday interest and as the subject of academic analysis, a disparaging position which diminishes acknowledgement of fashion's power to bestow both public recognition and personal (expressive, creative) fulfilment. Crucially, then, Advanced Style flies in the face of Twigg's description of the prevailing "Fashion System", as a hegemonic order that "presents an idealized world in which age does not feature, or in which it represents a dereliction, a corruption of the vision, a falling-off and failure, something to be excluded and ignored" (2013, p.11). Instead it lays claim to this territory for occupation by older women, asserting their presence and right to participate actively in the world of style and fashion rather than submit to the cultural imperative to withdraw into invisibility. In this sense it can be said to fulfil a kind of provocative, politicised purpose; for as Roland Barthes notes, "The wearing of an item of clothing is fundamentally an act of meaning that goes beyond modesty, 
ornamentation and protection. It is an act of signification and therefore a profoundly social act right at the very heart of the dialectic of society" (2006, p.97).

All this said, however, most of the women featured in the blog and book are also again, as in standard, youth-oriented fashion media, white, able- and slim-bodied. In the film, there are seven key subjects ranging in age from 62 to 95 . Here the audible range of voices and accents one hears once they move from still photography into the audio-visual gives a greater sense of difference among them, and the challenges of the physical impairments brought about by ageing are acknowledged; Jacquie, for example, is “legally blind". Yet one can't help but observe, despite the striking racial diversity that characterises New York, that just one of them - again, former Apollo Theatre dancer Jacquie - is black. Though Cohen's celebration of older women's style is not predicated on their affluence, a notable number of women in the book nevertheless carry what one might call signifiers of wealth (high-end classic designer labels, professionally-styled hair) that speak to the kind of class privilege that enables 'successful ageing'. In one widely circulated image from the book, for example, Joyce hugs a Chanel handbag to her chest, eyes closed as if embracing it, a blissful half-smile on her face. Subsequently, in the film she reveals her bag collection will form an inheritance for her granddaughter, affectionately telling her, "You never saw a number of the Chanel bags I have. You know I take very good care of them because I'm going to be giving them to you one day". Fashion in this moment is figured not simply as an act of expressive creativity, not merely a cross-generational 'feminine' pleasure that might be shared among women across ages, but as a commercial enterprise, and potentially an exercise in shrewd capitalist investment. 'Diversity' in Advanced Style, then, is perhaps more often about seeing older women strike confident poses in atypically colourful or distinctive, creative attire - in opposition to "the long tradition of age ordering in dress" which compels older women to move into "darker, duller colour; looser, longer cut and... more covered-up, self-effacing 
styles" (Twigg 2013, p.3) - rather than primarily about showcasing a broad diversity of older women dressed as such.

This snapshot does not constitute a complete picture, however. Importantly, by including a breadth of ages Cohen's film ensures that he does indeed explore advanced ageing, that is "the more challenging territory of deep old age" (Twigg 2004, p.71) that popular culture particularly shies away from exploring or representing. Ilona is seen caring for an old friend with dementia, for example, in a sequence striking for how it eschews more typical representations of the horror of this illness to instead capture the love and fondness that the women still patently share. "I can't buy green bananas any more" muses Ilona wryly, and indeed the film's oldest subject, 95 year-old style icon Zelda Kaplan, died during the course of filming in the 'FROW' (front row) at New York Fashion Week ("What a fabulous way to die!" marvels Tziporah). And importantly, as noted, the women's styles are not all by any means only accessed through wealth. Indeed, Sauers declares that, "the film showcases its subjects' diversity - the women have very different lifestyles, they come from different ethnic and class backgrounds, and their personal styles range from colourful and anarchic to sedate and classic" (2014, p.25). Certainly, their economic statuses vary significantly. Debra, for example, comments on the exorbitant expense of renting in New York and her "thrifting" is observed to be both a pleasure and financial necessity for her; meanwhile business-owner Lynn has been running her own boutique, 'Off Broadway', on the Upper West Side for 42 years, the website for which features jumpsuits retailing for almost $\$ 500$, a fact which doesn't entirely chime with her maxim in the film that "Money has nothing to do with style"iii. A number of the women featured evidently create their style from 'vintage' stores and 'upcycling' or fashioning their own designs, very much in keeping with the recent recessionary revival of feminine craft skills. In the film, Ilona makes her own false eyelashes by trimming her brightly coloured hair, while the book notes she is a "true original", creating 
her own style by "transforming old scarves into beautiful dresses" (Cohen 2012, np); elsewhere, Debra is seen excitedly grasping a pair of cardboard toilet-rolls and announcing her plans to transform them into bracelets. As Elizabeth Nathanson notes of the emergence of the resourceful young fashion-and-finance-savvy 'recessionista' in recent years, here the film offers 'an image of postfeminist femininity as defined by an efficient and frugal combination of production and consumption', which '[transforms] shopping into a kind of pleasurable work' (2014: 137). Thus the film suggests that imagination and industry are ultimately more necessary to achieving style than money; and in this respect, there is no excuse for women not to make an effort to participate, whatever their age or income.

And it is here that I want to begin to more fully unpack the seemingly universal sense of delight and approbation in Cohen's project, to point to the tensions for feminism at work within the Advanced Style philosophy. What of the 'silver-haired set' who don't make the Advanced Style cut? What of the lone woman we see Cohen tentatively checking out from behind in the street at the start of the film? Inspecting her more closely, as he draws near he evidently decides she doesn't have what it takes and walks away. Must she remain invisible, un-documented? In this moment, we see a critical gaze evaluate (an older) woman's fitness for purpose as the subject of the look in just as crude a fashion as the objectifying, sexualised male gaze on young women ranks and orders them. All style blogs are by nature selective, of course. Nevertheless the seeming inclusivity of the project surely crumbles here, since this moment exposes how the apparent drive to address the marginalisation and cultural invisibility of older women inevitably leaves many who don't hit the required benchmarks for senior 'stylista' status still out in the cold. 
Advanced Style captures how Cohen's subjects become minor celebrities, travelling to LA together to appear on The Ricki Lake Show, having business meetings with Discovery about a potential TV project and winning modelling contracts (both Jacqui and Tziporah feature in campaigns for high-end designer Lanvin). But the process is seen at times to provoke a certain competitiveness among some of them, and this notion of female rivalry is another familiar feature of the discourse of postfeminism: Cohen takes Lynn aside to have a quiet word about not dominating interviews; Tziporah wants to know whether anyone apart from her got to meet photographer Steven Meisel in the Lanvin auditions. Rather than 'advancing' representation somehow, then, one might ask whether Cohen's project merely surrenders older women into the trappings and judgemental hierarchies that confine younger women and compel them to always earnestly self-critique their appearances - so that by this measure women can now expect to be scrutinised, elevated or relegated alongside one another according to how they look via the relentless regime of postfeminism throughout the life course. Indeed, there is an established thread running through some feminist accounts of ageing which speaks of the liberation that 'invisibility' can bring older women, of some women's relief at no longer having to dodge catcalls or constantly moderate evaluations of their appearance, since older age relaxes these strictures and largely removes them from this orbit. As Germaine Greer has put it, "It is quite impossible to explain to younger women that this new invisibility, like calm and indifference, is a desirable condition" (1991, p.430). Elsewhere, de Beauvoir writes, "It is for women in particular that the last age is a liberation: all their lives they were subjected to their husbands and given over to the care of their children: now at last they can look after themselves" (1970, p.488) (my emphasis). Clearly, many women do not fit de Beauvoir's vision of familial caregiver. Still, what remains ambiguous in the new vogue for positioning older women as style mavens is the extent to which it represents a new permission for older women to at last delight in the self, to indulge 
"[looking] after themselves" as de Beauvoir might have it, versus it constituting a newly inscribed and prolonged pressure to remain demonstrably style-conscious into later life.

\section{About time: the Fabulous Fashionistas" "old lady revolution"}

Advanced Style is not the only film of late to have brought these questions and the "old lady revolution" Kreitzman speaks of so squarely onto the cultural agenda. As I have discussed elsewhere, Sue Bourne's Fabulous Fashionistas was met too by a hugely positive critical and popular reception in Britain (Jermyn, 2015). It holds obvious parallels with Advanced Style, as six spirited older women who all still relish the sartorial world are profiled, each of them similarly introduced going about their regular activities and talking about their style, all of them white and most of them again able- and slim-bodied, in line with the fashion industry's dominant strictures. Bourne's film arguably does rather more to capture the women's lives and characters outside of their interest in clothes, however. Indeed, in my interview with her she reflected that having originally planned to film in the US in conjunction with Ari Seth Cohen, an unforeseen shift to filming in UK turned out to be "a bonus" because she had found the US women to be so wholly “all about fashion... and when I met them I couldn't get so much about the spirit and the background I was after" (2014). Bourne is one of the UK's leading observational documentary filmmakers, director and producer of close to 20 documentaries, who explained that the film's apparent focus on fashion had been a ruse to enable Fabulous Fashionistas to be made, providing the sparky 'angle' she needed to get commissioned, in order to furtively make the documentary about ageing she actually wanted to film. She described the objectives and motives behind the project, both as a filmmaker and as a woman in her 50s dissatisfied with the available repertoire of images of older women:

Basically what I was looking for was a template for the next 30 years... that was my starting point, looking for role models... But I knew if I went to any broadcaster in Britain and went, 'I want to make a film about these wonderful 
older feisty women' they would tell me to take a hike... so I had to come up with some clever way to conceal the fact that I was talking about age... and I just sort of pretended, really, that it was about style, but it isn't (Bourne 2014).

Instead, what the film is about, according to Sue Kreitzman (who like Bridget Sojourner features both in the Advanced Style blog and book, and Fabulous Fashionistas), is "life and death and hormones and everything” (2015).

\section{FIG 2 HERE - Caption:}

\section{Bourne's company flyer for Wellpark Productions showcases the success of Fabulous}

\section{Fashionistas (photo by Marina Vorobieva)}

As the film's (unseen) interviewer and narrator, Bourne introduces all the subjects. Jean, we learn, met her husband aged 15 and had been recently widowed after 56 years together, prompting her to get a job at Gap in her 70s; Bridget is a former charity healthworker, who now campaigns on ageism and diversity, and who manages to maintain her flamboyant style on a state pension by frequenting charity shops; Gillian is a celebrated dancer and choreographer (of Cats and Phantom of the Opera fame), still working at nearly 90; Daphne is “the fashion world's go-to older model”, whose long-dormant modelling career was reignited in her 70s after she was widowed; Sue was once a highly successful food writer and TV cook who reinvented herself as an artist; Baroness Trumpington is a former Mayor of Cambridge who sits in the House of Lords, and whose picture 'went viral' on the internet in 2011 after she was captured on camera sticking two fingers up at Lord King as he delivered a speech. 
Though the women's histories and economic statuses, as well as their styles, are again quite different they are all in their way aspirational visions of ageing well; physically and socially active and independent, engaged and invested in the world, humorous and lively, they are still committed too to the feminine pleasures of style and grooming. They are indeed Bourne's hoped-for "role models"; "We'd all like to look this good at 80", she reflects in voiceover as Gillian performs her daily stretching routine, noting further that, "Whatever her regime and philosophy we should all probably adopt it tomorrow. She looks and moves and thinks like a woman half her age". The admiration implicit in this does not sit entirely logically with the earlier affirmation that, “[It's] not about looking younger. For all these women it's about individual style and attitude". Consistently, though, the apparent "trick" to achieving all this, which Bourne entreaties Gillian to reveal, arguably pivots keenly on maintaining a physically active routine and undertaking ongoing work of some kind (Bridget is seen toiling as a gardener as well as a campaigner; Jean is shown working in a boutique, and since the film was broadcast has also become a model). The women share a sense of industry and drive, in spite of the vicissitudes of ageing, that the film invites viewers to admire and aspire to, since as Gillian observes, “It's all about having a purpose, that's why I think to retire is dangerous".

Though, as their biographies make clear, some of the women already had media experience, since the film was broadcast this media presence has expanded further still for them all, from Gillian being made a Dame, to Jean's portrait winning second place in the UK's 2014 BP Portrait Award, to Baroness Trumpington publishing her autobiography. As with some of Advanced Style's subjects, Jean, Bridget and Sue have been contracted for a number of modelling shoots and advertising campaigns. But quite beyond this, the women have been widely called on as cultural commentators speaking out against ageism. For 
example, continuing her history of activism, in interview Bridget told how, "Now I've become this 'media star', I'm using it to develop workshops on ageing, going into schools with 16 to 18 year olds", explaining that she runs diversity awareness sessions where she screens the film to help explore ageism, both with students and trainee care-workers (Sojourner 2015). Meanwhile, Sue Kreitzman was one of the featured artists in premier London department store Selfridges' 2015 Bright Old Things design campaign, given a dedicated window-display in one of the most coveted shopping sites in the word, and describing in interview how she is regularly contacted by the BBC and other media as "a spokesperson on ageing". As she went on: "I never thought I'd be famous for being an old lady... And I'm delighted, because I'm quite a viable old lady... It's about making a difference, and connecting with people" (2015). These stars of a documentary supposedly about (the 'trivial' world of) fashion, then, have via the film claimed a rarely seen public platform as older women, demonstrating against the grain of a media that overwhelmingly erases them that there is an audience for them.

As with Advanced Style, though, the film's beguiling air of optimism belies a tension around the nature of its underlying politics, which lends itself at times to a neoliberal agenda. On the one hand Sue proclaims positively that "Growing old is a privilege, it's an adventure". But on the other, ageing is sometimes figured in familiar ways as an external, invasive force that the individual must take responsibility for deflecting, neatly exemplifying postfeminism's acceleration of 'a sense of time as threat' (Negra, 2009, p.47), as when Gillian tells us that "I think you have to pit yourself, if you like, against the ageing process and you just mustn't allow it in... the minute you give an inch, you know, life or illness or something will take a mile". While the health benefits of 'staying active' in older age seem quite incontrovertible, in keeping with the dictates of neoliberalism, the admiring account of how these women all remain thoroughly industrious marks them also as still 'useful' citizens. 
Such an aspiration demands today that the individual never stop driving forward, never relinquish a goal-led mindset, in contrast to de Beauvoir's observation in 1970 that one of the "compensations" for the adversities of ageing for some older people was precisely that "they no longer have to make any effort, and they are allowed to be idle... According to Jouhandeau... 'The approach of old age brings a kind of absolute leisure. There is no longer the least need to exert oneself for success of any kind... What a relief!'” (1970, pp.461-62) a sentiment which today clashes astoundingly with the values popularised by neoliberalism.

No matter that these women are all 70+. Like the subjects of Advanced Style, they fit readily into the framework conceptualised by Nathanson in relation to 'young' women pursuing the rewards of fashion and style in the contemporary moment and within the constraints of the recession, in which 'happiness is predicated on creative selections, arrangements and resourcefulness'; and where 'postfeminist taste' means that 'successful modern femininity involves making productive and creative choices that help communicate individuality to the public eye and contain the promise of a satisfying future full of opportunity' (Nathanson 2014, p.148). On one level one might say the film exposes the (very often concealed) labour of postfeminism's emphasis upon relentless "self-monitoring" (Gill 2007) that extends into the pursuit of 'ageing well', since it shows how the women's regular fitness regimes and activities do not always come easily. Rather, these routines are seen to be often punishing and uncomfortable, especially given the film's recognition of the women's various surgeries and maladies, even if the results are ultimately gratifying - Jean and Daphne's success as models in later life (like Tziporah and Jacqui's success in the Lanvin campaign) is inextricably bound up in their maintaining lithe bodies that fulfill the fashion industry's 'clothes hanger' ideal. However, this body type is far removed from the postmenopausal physiognomic changes many women experience, which may include a lowering of the bust-line and thickening around the waist (in part as metabolisms slow down with 
ageing), and which make such slender corporeality even more unattainable for them than it is for the majority of pre-menopausal women ${ }^{\mathrm{iv}}$. But at the same time Fabulous Fashionistas suggests that women have a choice in all this, that to not endure the kind of discomfort we see Gillian undertaking in the pursuit of ageing well, to relent and "give [the ageing process] an inch" as she puts it, would be the result of a kind of personal shortcoming.

As in Advanced Style, the film claims via Bourne's voiceover that "It's not about money", and this denial of economic status as a determining factor in the ageing process and in the likelihood of one being deemed to have 'aged well' is deeply problematic. As Susan Sontag noted, undeniably ageing "varies according to social class. Poor people look old much earlier in their lives than do rich people... women who keep their youthful appearance the longest... [are the] women who lead unstrenuous, physically sheltered lives, who eat balanced meals, who can afford good medical care, who have few or no children... Aging is much more a social judgment than a biological eventuality" (1972, p.32). While the discourse of the 'grey tsunami' makes much of the acquired wealth and generous pensions of the 'babyboomer' generation, it is nevertheless the case that the world over women both live longer and earn less than men, and hence that older women are demonstrably more likely to live in poverty (see, for example, Fidel 2012; Moore 2013). None of this is to deny the significant accomplishments of Fabulous Fashionistas in challenging and expanding dominant representations of older women as either care-facilitators (useful primarily for looking after young grandchildren or ailing spouses) or dependents themselves (and thus of no use at all). But the repudiation of attention to class or income as significant to women's experience of ageing shifts the focus on to the individual to take charge of their own healthy, 'successful' ageing in line with a neoliberal discourse, denying the larger social structures at stake that incontrovertibly impact on ageing and suggesting instead that a 'can-do' attitude is all. Thus, invoking the habitual makeover paradigm of postfeminist discourse, Bourne's 
voiceover ponders, “Maybe old age doesn't have to be so bad after all. Instead of your horizons shrinking, you could even find yourself with a brand new career" - but attention to questions of access, privilege or cultural capital in achieving this (presuming indeed one aspires to it at all) are never contemplated ${ }^{\mathrm{v}}$.

In interview Bourne described Fabulous Fashionistas as a "very gentle, hopeful film”. This is an apt account, and as such, any explicit grappling with the difficult political terrain outlined above was never its intention. She also pondered that, "I'm not sure it's what Channel 4 wanted", elaborating that she believed it wasn't "on-message for them" (2014) that is, it was not quite "edgy" enough, not provocative in the vein of recent controversial (and 'successful' with regard to viewing figures and column inches won) reality series like My Big Fat Gypsy Wedding (Channel 4, 2011 - ) or Benefits Street (Channel 4, 2014 - ) and not so readily in keeping with a drive to target a younger demographic. Hence, to her disappointment, when Fabulous Fashionistas was broadcast the channel buried it in the 10pm transmission slot and she noted they had done little to follow up on the animated reception that met it, which had included calls from leading British fashion and style journalists Hadley Freeman, Sali Hughes and Caryn Franklin to produce a whole Fabulous Fashionistas series ${ }^{\mathrm{vi}}$. This may well suggest that for Channel 4, the appeal of the film's premise was judged to be worth a commission but nevertheless finite, its content deemed to hold novel but only passing interest for its audiences. Was Bourne's experience of Channel 4 demonstrative, then, of how contemporary media possess only a whimsical curiosity in the pursuit of more diverse images of ageing women; evidence that the seeming tentative absorption of older women into the imaginative, aspirational (youthful) world of fashion is itself just a 'trend' to be tried on for size and discarded before becoming worn?

\section{Older women defining 'cool': subversion vs exploitation}


Back in 2008 when Ari Seth Cohen commenced his blog and began to get media attention he was quickly positioned as doing something quite visionary. Advanced Style imaginatively drew on the cachet of an established street-style photography format, then subverted it; as Naomi West's Telegraph fashion profile of the site observed in 2010, it adopted "the template of the Sartorialist and Facehunter - websites that consist of street shots of the impeccably hip" then added a twist, to celebrate "strikingly dressed senior citizens" (West 2010). Five years on from West's article at the current time of writing, media coverage of the recent turn towards older women by the wider fashion industry gives continual acknowledgement to how Cohen's project led the way, becoming eventually a significant 'brand' of its own that acted as a pioneer for established major labels. Indeed, West's profile of Cohen ends rather prophetically: "In the future he would love to work with brands to help them address this neglected demographic ('It would be great to get these cool women in ads')" (ibid). And it is to the recent vogue for older "cool women" in Céline and Dolce \& Gabbana's (D\&G) SS15 advertising campaigns, presciently conjured here by Cohen, that I now turn by way of conclusion, for the manner in which the contradictory and oppositional responses to them crystallise the tensions at stake in this shift.

Importantly, in neither of these campaigns are older models being used to promote 'older women's' products; these are images being used to sell the aspirational wares of highend fashion designers, not anti-ageing moisturisers or mobility aids. Céline's use of a seated rake-thin Joan Didion wearing a pair of oversized sunglasses and a classic black turtleneck entailed the adoption of an older woman recognised and much revered as a public intellectual being reimagined and repositioned in the world of fashion. And while some commentators such as Hadley Freeman expressed dismay at seeing "the fashion industry [reducing] brilliant human beings to mere statements about an aspirational lifestyle" (2015) others embraced the campaign's 'uplifting' vision and spoke warmly about how Didion's striking pose 
communicated gravitas as well as style; "The real point here is just how extremely clever she not only looks, but palpably is", observed The Telegraph (Armstrong 2015). In contrast, D\&G's flamenco-themed campaign featured three unknown, 'regular' and more thickset 'senior-inas' (ibid) who importantly have the kinds of more commonplace older, postmenopausal bodies which as pointed to above are anathema to the fashion industry's ideal. Hence they are not wearing D\&G SS15 ensembles, but rather sporting ornate bags and tiaras while dressed in traditional widow's mourning attire, while in some images they serve as mere backdrop to the 'real' models, constituting stage-dressing for the conventional lithe, long-legged, young women actually wearing the season's clothing line. They point, then, to an important contradiction at stake in the recent surge of designers adopting older women to front their advertising campaigns; which is to say that older women are still not necessarily the imagined shopper being targeted, still not the ideal consumer, in that while the design of most of these clothes does not accommodate the bodies of the majority of all women, they make no attempt at all to address an older women's likely physiognomic changes, in terms of cut or size range.

Contradictorily though, the media reception of the shift to older models included numerous commentators observing too that it signaled the industry cannily acknowledging that older women constitute an important and expanding market, who as consumers want to see women closer to their own age modelling clothes rather than pre-pubescent girls (see Marriott 2015). The industry treads an uncomfortable line here though: Twigg's research found that clothes designers across the price spectrum were often nervous about the potentially negative impact of their brand being understood as pitched at older consumers (2013, pp.126-7). In this light, while the older women in these designer campaigns might connote desirable qualities such as resilience, cerebralism and experience that brands wish to align themselves with, in themselves they function at the level of accessory; as Bridget 
Sojourner noted wryly of the Céline campaign in interview, "They're jumping on a bandwagon" (2015). Hence some critics voiced concern about the exploitative nature of this 'trend', seeing it as the industry's latest cynical effort at 'edginess' and certainly not evidence of it undergoing a process of increasingly reflective social awareness, or taking on new ethical responsibility to promote diversity. Indeed, the recent trend for young women dyeing their hair grey (cf the \#GrannyHair hashtag on Instagram), and thus inverting the cultural imperative for women to colour their hair precisely to deny it turning grey is another case in point here. Does this fashion statement showcase the youthful subject's 'edgy' or somehow subversive style; her (also somehow subversive) solidarity with older women and a refusal of gerontophobia; or some measure of both? (see Alexander, 2015). The question remains, then, is it really now 'cool' to be an older woman?; or cool to be a young person who declares she admires older women? - in which case, do older women remain somehow 'Other'?

Twigg notes that "at the heart of the rhetoric of fashion is the language of renewal and rebirth. Clothes offer the possibility of constant renewal of the self' (2013, p.14). In this respect, and when considered alongside its longstanding status as an inherently 'feminine' realm where consumerism is particularly acutely marked as a female pastime, fashion is a business which may arguably constitute the quintessential postfeminist, neoliberalist industry. Even while proffering the anticipation of the transformational in the short-term, clothes and fashion always simultaneously carry the knowledge of an imminent turnover; the understanding that something more 'on-trend' for those interested in the cutting-edge, or just something which somehow comes to seem more desirable, will always be in the offing. While the rise of 'vintage' shopping promotes the idea of the (perhaps more affordable) collectible, in most clothing consumption it is the case that another item will eventually surpass and replace what is had and what satisfies now. Twigg's research shows that older women have been drawn into what is known as "the faster shopping cycle", underlining the 
sense that despite the pervasive divisive generationalism of postfeminism, its focus on continued personal reinvention and maintenance is not merely what one might call "a young woman's game"; hence "women over seventy-five now shop for clothes as often as those aged sixteen to thirty-four did in the early 1960s" (2013, p.121). Like the seasonal change that leads the fashion industry's constant metamorphosing, postfeminism posits that a better self and the capacity for another (better) makeover is always on the horizon for contemporary women, and ageing increasingly functions neither as a barrier to nor an escape from this directive. While postfeminism may seek to enflame rivalry between women across the life course and history's 'waves' of feminism, what all this points to is a landscape where all but the very oldest women are increasingly compelled to adhere to the same strictures of public scrutiny, self-surveillance and the incessant reworking of the self. For this reason, it is increasingly pressing that as the visibility of older women seems, for the moment at least, to be gaining momentum in popular culture, feminist media studies must seek to more closely interrogate the contexts and implications of this shift, and in the process begin to redress the historical marginalisation of older women in its own work.

\section{Acknowledgements}

With many thanks to Su Holmes and Nova Matthias; to colleagues at The Life Writers of London and the University of Winchester seminar series for inviting me to give papers and sharing discussion around this work, most especially Oline Eaton and Neil Ewen; and to the editors and anonymous reviewers at FMS for their helpful and generous feedback

\section{References}

Alexander, Saffron (2015) '\#Granny Hair: Why is everyone dyeing their hair grey?', The Telegraph, July 3, available at: 
http://www.telegraph.co.uk/goodlife/11708433/GrannyHair-Why-is-everyone-dyeingtheir-hair-grey.html [accessed December 9 2015]

Armstrong, Lisa (2015) “January's silver-haired fashion stars”, The Telegraph, January 9, available at: http://fashion.telegraph.co.uk/article/TMG11333480/Januarys-silverhaired-fashion-stars.html [accessed April 3 2015]

Barthes, Roland (2006) "Fashion and the Social Sciences" (first published 1966), reprinted in The Language of Fashion, Oxford and New York: Berg

Bourne, Sue (2014) Personal interview with Deborah Jermyn, London, November 19.

Cohen, Ari Seth (n.d.), Advanced Style blog, available at: http://advancedstyle.blogspot.co.uk/

Cohen, Ari Seth (2012) Advanced Style, New York: powerHouse Books

de Beauvoir, Simone (1970) The Coming of Age, English translation by Patrick O'Brian, New York: G. P. Putnam's Sons (first US edition, 1972)

Fidel, Emma (2012) “Women live retirement in poverty at higher rates than men”, July 25, bloomberg.com, available at: http://www.bloomberg.com/news/articles/2012-0725/women-seen-living-retirement-in-poverty-at-higher-rates-than-men [accessed April $32015]$

Freeman, Hadley (2015) “It's great that Céline is celebrating Joan Didion - but to sell accessories?", The Guardian, January 12, available at: http://www.theguardian.com/fashion/2015/jan/12/celine-joan-didion-literary-herofashion-advertisement [accessed April 3 2015]

Friedan, Betty (1993) The Fountain of Age, Vintage: London 
Friedman, Vanessa (2015) “Fashion's Two-Faced Relationship With Age”, January 7, available at: http://www.nytimes.com/2015/01/08/style/fashions-two-faced-

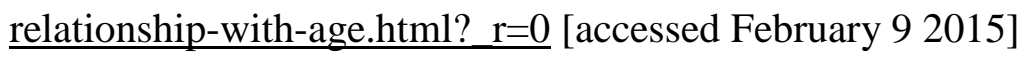

Gill, Ros (2007) “Postfeminist media culture: elements of a sensibility”, European Journal of Cultural Studies 10 (2), pp. 147-166.

Greer, Germaine (1991) The Change: Women, Ageing and The Menopause, London: Hamish Hamilton

Jermyn, Deborah (2015) “'Don’t Wear Beige - It Might Kill You’: The Politics of Ageing and Visibility in Fabulous Fashionistas', in Deborah Jermyn \& Su Holmes (eds) (2015) Women, Celebrity and Cultures of Ageing: Freeze Frame, Basingstoke: Palgrave Macmillan, pp. 127-145.

Jermyn, Deborah \& Su Holmes (eds) (2015) Women, Celebrity and Cultures of Ageing: Freeze Frame, Basingstoke: Palgrave Macmillan

Kreitzman, Sue (2015) Personal interview with Deborah Jermyn , London, February 13 Morganroth Gulette, Margaret (1997) Declining to Decline: Cultural Combat and the Politics of the Midlife, Virginia: University of Virginia Press.

Morganroth Gulette, Margaret (2004) Aged by Culture, Chicago: University of Chicago Press.

Marriott, Hannah (2015) “Joan Didion and Céline: Why old age is having a fashion moment", January 7, The Guardian, available at: 
http://www.theguardian.com/fashion/shortcuts/2015/jan/07/joan-didion-and-celinewhy-old-age-is-having-a-fashion-moment [accessed April 4 2015]

Moore, Heidi (2013) "Living longer and earning less: are elderly women doomed to be poor?", The Guardian, September 26, available at:

http://www.theguardian.com/money/us-money-blog/2013/sep/26/are-elderly-womendoomed-poverty [accessed April 3 2015]

Negra, Diane (2009) What a Girl Wants? Fantasizing the Reclamation of Self in Postfeminism, London and New York: Routledge

Nathanson, Elizabeth (2014) 'Dressed for Economic Distress: Blogging and the "New" Pleasures of Fashion' in Diane Negra and Yvonne Tasker (eds) Gendering the Recession: Media and Culture in an Age of Austerity, Durham: Duke University Press, pp. 136-160.

Sojourner, Bridget (2015) Personal interview with Deborah Jermyn, London,February 10.

Segal, Lynne (2013) Out of Time: The Pleasures and The Perils of Ageing, London and New York: Verso

Sontag, Susan (1972) “The Double Standard of Aging”, The Saturday Review, September 23, pp. 29-38, available at: http://www.unz.org/Pub/SaturdayRev-1972sep23-00029:30 [accessed April 3 2015]

Twigg, Julia (2004) “The body, gender and age: feminist insights in social gerontology", Journal of Ageing Studies, 18, pp.59-73 
Twigg, Julia (2013) Fashion and Age: Dress, the Body and Later Life, London and New York: Bloomsbury

West, Naomi (2010) "Ari Seth Cohen: the man who blogs about the silver stylistas", The Telegraph, April 8, available at:

http://fashion.telegraph.co.uk/article/TMG7564618/Ari-Seth-Cohen-the-man-whoblogs-about-the-silver-stylistas.html [accessed March 24 2015]

Williams, Melanie (2015) “The best exotic graceful ager: Dame Judi Dench and older female celebrity" in Deborah Jermyn \& Su Holmes (eds) Women, Celebrity and Cultures of Ageing: Freeze Frame, Basingstoke: Palgrave Macmillan, pp.146-161

Wilson, Elizabeth (1985) Adorned in Dreams: Fashion and Modernity, London: I. B. Tauris (New Edition, 2003)

Woodward, Kathleen (1999) Figuring Age: Women, Bodies and Generations, Indiana: Indiana University Press.

\section{Films}

Advanced Style. Directed by Lina Plioplyte. US, 2014.

Fabulous Fashionistas. Directed by Sue Bourne. UK, 2013.

\footnotetext{
${ }^{\mathrm{i}}$ The widespread interest meeting the Didion campaign underlines how, even in this seemingly changing climate, cultural representations of 'older' women still rarely extend to octogenarians and beyond, and for this reason (given Didion was 80 at the time of the
} 
campaign) Céline's advert became the subject of especially intrigued media dissemination. Furthermore, the clearly diverse ages of the women listed here in this brief survey of older women who have appeared recently in the fashion spotlight underlines how very subjective definitions of 'older' remain.

ii So too is it important to note the difference between 'fashion' versus 'clothing' or 'dress', since in Twigg's words clothing and dress can be understood "as universal aspects of social being, applying to everyone, rather than to special or elite features as promoted by parts of the fashion industry, where fashion can be an exclusionary term" (2013, p.120).

iii Since the writing of this article, Off Broadway boutique closed in September 2015 following Lynn Dell Cohen's death in June 2015.

${ }^{\text {iv }}$ Indeed Twigg notes how "One of the ways [TV] makeover experts like Trinny and Susannah, Gok Wan and others achieve a stylish and younger look among the older women they dress is by using controlling underwear and tight cut that has the effect of imposing a younger, feminine figure. In this way they reconstitute older bodies" $(2013, \mathrm{p} .60)$. At the same time, conversely some older women worry at becoming too 'gaunt' or thin, especially as muscle mass declines with ageing.

"In keeping with and celebrating this theme, the Selfridges "Bright Old Things" campaign in 2015 which featured Kreitzman specifically focussed on older designers who had changed direction and sought out design careers later in life after foregoing earlier occupations. 
${ }^{\text {vi }}$ All these commentators were enthusiastic tweeters regaling Fabulous Fashionistas on the night of the broadcast, September 172013 (see @HadleyFreeman, @Caryn_Franklin, @ salihughes). 